\title{
Managing a portfolio of green projects: Drivers of efficiency and the role of complementary projects
}

$\underline{\text { Authors }}$

Xun Tong, U. of Groningen, x.tong@rug.nl

Kevin Linderman, U. of Minnesota, linde037@umn.edu 


\title{
Managing a portfolio of green projects: Drivers of efficiency and the role of complementary projects
}

\begin{abstract}
Increasingly, multinational enterprise buyers concern their suppliers' green performance with respect to energy consumption and waste emission because stakeholders consider multinationals are obligated to ensure that their suppliers make continuous progress in managing environmental issues. However, operations managers confront the challenge of how and in what ways to improve suppliers' green performance. Recently, buyer and supplier firms have begun to formulate a green project portfolio in a coordinated manner to enhance supplier's green performance (e.g., buyer initiated-supplier voluntarily implemented green projects). This research examines the drivers of green project portfolio efficiency and the role of complementary projects in suppliers. We develop hypotheses describing the main effect of the portfolio focus, the interaction effect of firm's financial strength, and the complementary role of social and technical projects on portfolio efficiency. The project-level data of suppliers come from a world-leading automobile company and the firm (supplier)-level data is obtained from the Dun \& Bradstreet company. We test our hypotheses using data envelopment analysis and Simar \& Wilson (2007)'s two-stage, semi-parametric models. The empirical results suggest that a more focused green portfolio enhances the firm's ability to benefit from implementing green projects, which is contingent upon the firm's financial strength. Also, we find that a synergy of social and technical green projects can create congruence thereby increasing portfolio efficiency. Our research contributes to the green supply chain management and project management literature by revealing the drivers of green project portfolio efficiency and the role of complementary projects. The research findings should be helpful for managers to improve the efficiency of green projects implementation.
\end{abstract}

Keywords: green supply chain; project portfolio management; complementarity; data envelopment analysis 


\section{Introduction}

The increased energy consumption and growing volume of waste emission have become major environmental concerns in recent decades (Jacobs, 2014; Zhou, et al., 2017). In responding to these problems, green projects that aim to improve environmental performance have been increasingly implemented by firms. In particular, in a global supply chain context, multinational buying firms and their partner suppliers have begun to formulate green project portfolio in a coordinated manner to improve suppliers' green performance (Plambeck \& Taylor, 2015; Tong, et al., 2018). A green project portfolio adopted by a firm encompasses several green projects, each with its own focus on different practices for reducing energy consumption and/or waste emission, but competing for limited resources. For example, Walmart released its green project portfolio attempting for developing a greener supply chain, which includes projects of increasing renewable energy adoption, reducing emissions within its global supply chain, sourcing from suppliers which are third-party certified as sustainable, and so on (2018 Global Responsibility Report Summary). Nevertheless, such initiatives require significant investments and organizational change efforts; they thereby can be costly and disruptive. In the academic literature and from a practical perspective, it is less clear that, to what extent firms could benefit from implementing green projects, especially when firms invest multiple resources (e.g., human capital and money) and target for multiple performance outcomes (e.g., reduce gas emission and save water usage). Managers also confront the dilemma of whether to implement a broad (a wide range of differing projects) or a focused (a limited number of differing projects) green portfolio considering firm's contingency factors (e.g., financial performance). In this study, we define project portfolio focus as the extent to which different types of projects are implemented within a portfolio. Moreover, if several different types of projects are implemented within a green portfolio, it remains largely unknown whether a specific type of green project is more impactful in triggering portfolio efficiency when combined with another type of project than it 
is implemented alone. Practically, managers concern the green project portfolio efficiency, meaning the efficiency of transforming green inputs (human resources, monetary investments, time, etc.) to green outputs (emission reduction, cost savings, energy saving, etc.) through green projects implementation. An understanding of possible conjunction between different types of projects (i.e., complementarities) may enhance the manager's ability to achieve intended green performance.

Previous research has established the effectiveness of organizational change efforts towards socially responsible operations on performance (Dhanorkar, et al., 2017; Glaser, 2017; Kacperczyk, et al., 2015). However, most of them used a single input-single output framework to investigate the organizational performance whereas the performance is compared against a single and absolute measure (e.g., the counts of violations for environmental codes within the unit of analysis), therefore neglecting a multiple (e.g., the number of inputs or outputs could be more than one) and relative (performance may be compared with other firms) view of firm's capability towards attaining green objectives. In this study, we are prompted to incorporate multiple input and output variables in estimating green projects performance across various firms (Cook, et al., 2014), which extends the literature on green performance employing the data envelopment analysis for estimating relative efficiencies of green project portfolios implemented by different firms.

Research is inconclusive on the efficiency of a portfolio under a focused vs. broad portfolio composition. This paradox has led to mixed results in the literature. For instance, some research has urged the importance of a focused strategy for short-term projects which attempt to exploit the existing knowledge and technologies (Eriksson, 2013), arguing that focus may trigger in-depth learning. On the other hand, scholars also assert that relational capital could be created through projects alliance, which allows for potential explorations from one project to another (Aaltonen \& Turkulainen, 2018). Therefore, a broad portfolio consisting of a wide 
range of projects may be more beneficial for firms to trigger exploratory activities through relational capital between different projects. Collectively, the mixed results call into question: in the green project management context, given that managerial attention and resources for implementing projects are limited (Dhanorkar, et al., 2017), whether a focused or a broad portfolio would be more beneficial. Also, Maylor, et al. (2018) argue that "we need to understand how projects relate to their environments" because no project should be treated as an "island". In this regard, this study endeavors to understand one critical firm contingency factor, i.e., financial strength, on the relationship between portfolio focus and efficiency. To this end, the first research question guiding this study follows.

$R Q(1):$ Whether and to what extent green project portfolio focus would affect the efficiency? If portfolio focus affects efficiency, whether and how firm financial contingency will moderate such relationship?

Several strategy (Riley, et al., 2017) and operations management scholars (Malhotra \& Mackelprang, 2012; Nair, et al., 2013; Swink \& Nair, 2007) have found complementary relationships between different resources. Some previous works relating to complementary resources, e.g., complementary technologies (Anderson Jr \& Parker, 2013), organizational acceptance and intensity of use in E-procurement infusion ( $\mathrm{Yu}$, et al., 2015), and complementary investment in information systems (Bendoly, et al., 2012), suggest that complementarities exhibit significant learning effects, thereby enabling firms to attain higher performance benefits. In view of the different types of green projects, they can be largely divided into social and technical green projects where the former concentrates on human capital training and organizational management improvement while the latter centers on process optimization and technology innovation (S. K. Srivastava, 2007). As such, based on the sociotechnical systems theory, we conjecture that within a portfolio, there could be a complementary effect between these two types of green projects, which may lead to a higher green portfolio performance. Understanding an optimal conjunction between different types of green projects 
would be of enormous value to portfolio success. Hence, we propose the second research question in this study.

$R Q(2):$ Whether and to what extent there is a complementary effect between social and technical green projects?

\section{Conceptual background}

Our research relates to the following three streams of literature, namely, project-driven organizational change efforts, project portfolio management, and complementary resources from a socio-technical systems view.

\subsection{Project-driven organizational change efforts and environment performance}

Organizational change literature suggests that interventions can be used as an effective means to improve routines within an organization (Glaser, 2017; Kacperczyk, et al., 2015; Kuusela, et $a l ., 2017)$. Therefore, managing change is deemed critical for organizations to achieve overall efficiency and deal with external threats, dynamics, and regulations such as governmental codes for compliance (Greve, 1998; Kotter \& Schlesinger, 1989). Organizational intervention refers to the process that commences with a diagnosis of problems, identifies changes needed to address inefficiencies and eventually followed by the refinements and improvements of the current internal processes. The initiatives could be carried out by the organization itself or promoted by the external agencies (e.g., environmental protection agency). There is a line of research investigating organizational change efforts which treat projects as intervention process to the internal routines (Criscuolo, et al., 2017; Dhanorkar, et al., 2017; Jonas, 2010; Swink, 2003). Such intervention projects include environment enhancement projects, R\&D projects, technology improvement projects, etc. For example, the regulatory agency can provide supportive programs (e.g., technical assistance) towards helping organizations to enhance environmental performance (Dhanorkar, et al., 2017). In addition, in a supply chain context, organizational intervention initiatives also can be implemented in a coordinated manner 
between a buyer and a supplier (Karaer, et al., 2017; Plambeck \& Taylor, 2015; Tong, et al., 2018). For example, a buying firm may first "intervene" in the supplier's internal process to identify potential problems and provide constructive recommendations for improvements. Suppliers may take a role of the "change agent" (Battilana \& Casciaro, 2012) to implement improvements.

\subsection{Project portfolio management}

Project portfolio management centers on selecting and prioritizing a mix of potential projects and later managing each project within a portfolio to maximize return-on-investment. Portfolio management has concentrated on managing a mix of projects competing for resources and managerial attention to cope with corporate change goals (Chao, et al., 2009; R. G. Cooper, et al., 2006; M. K. Srivastava \& Gnyawali, 2011). More recently, portfolio management has been widely used in the new product management whereas a resource commitment - flexibility dilemma exists to affect the performance of new product development project portfolio management (Gunther McGrath \& Nerkar, 2004). This line of research insights into the critical role of project focus and resource allocation within a portfolio. One of the primary goals of project portfolio management is to "achieve focus" (i.e., have only limited types of projects) and to "resource the 'great' projects" (R. G. Cooper, et al., 2006). Consequently, portfolio focus may play a significant role in realizing performance outcomes. On the other hand, previous studies assert that project efficiency is triggered by contextual characteristics of the focal firms (Tang, et al., 2012; Winkelbach \& Walter, 2015). Therefore, firm contingency factors such as financial strength may interact with project characteristics to affect the efficiency.

\subsection{Complementary projects: A socio-technical systems perspective}

Hutchison-Krupat and Kavadias (2018) assert that firms need to consider the "cross-functional nature of collaborative tasks" in implementing portfolio selection. The notion could also apply to green project portfolio selection since when implemented jointly, differing natures of green 
projects within a portfolio are likely to produce complementarities or exclusiveness in affecting performance outcome. Previous research in operations management stresses that a complementary effect exists between organizational capabilities to enhance performance (Malhotra \& Mackelprang, 2012; Nair, et al., 2013; Swink \& Nair, 2007; Tsai, et al., 2013). On the one hand, projects intended to improve green performance can differ from one another in terms of their functionalities. For instance, employee training-enabled energy saving and process optimization-enabled emission reduction are two different approaches. On the other hand, the conjunction of the two differing projects may produce complementarities. In other words, interdependencies may manifest across projects (Verma, et al., 2011), thus leading to superior overall performance than when a singular project is presented. Previous research has rarely looked into such possible complementarities among different green projects.

Socio-technical systems theory insights into how social components could provide a supporting structure for technical components and vice versa. The former encompasses human aspects with regard to social interactions within organizations (Hyer, et al., 1999) while the latter concerns methods and procedures to transform inputs into outputs (Liu, et al., 2006). As such, the social projects and technical projects within a green project portfolio may display complementarities in improving portfolio performance.

\section{Theory and hypothesis development}

\subsection{Portfolio focus and efficiency}

Supplier firms can implement a variety of categories (a broad portfolio) or a limited number of categories (a focused portfolio) of projects. There has been a well-known dilemma existing between volume-variety spectrum in the literature (Maylor, et al., 2018), arguing that it is critical for firms to select from a diversified and focused strategy. As discussed by Maylor, et al. (2018), it is critical to consider the "selection and prioritization of projects" in understanding 
the effectiveness of project portfolio management. Hence, the formulation of a portfolio can influence the efficiency of projects management. According to the Attention-based view of the firm (Ocasio, 1997), attention is considered a scarce resource for organizations to allocate in implementing changes (Dhanorkar, et al., 2017). In the project management context, individual projects within a portfolio can compete for available resources such as time, monetary investment, human capital, and managerial attention. As such, firms need to optimize their portfolio by properly selecting and implementing projects to be in alignment with their overall strategy.

Abundant project management literature suggests that a portfolio consisting of a broad range of projects may introduce a conflict between goals and imbalance of resource commitments (Jonas, 2010; Maylor, et al., 2018). This may occur due to that the competing managerial attention is unable to be allocated properly across a broad range of projects. Specifically, project goal discrepancies caused by different aspects of environment improvement foci that exist in different projects may hinder goal clarity, thus creating a conflict between goals to decrease the overall efficiency of projects management. Moreover, a portfolio consisting of various differing projects may require intensive cross-project resource planning (Levine, 2005), resulting in resources and attentions thinly spread among a large number of distinct projects. Therefore, a broad portfolio containing a wide range of competing projects may not be able to allow for efficient exploitation of resources allocated to the green portfolio management than that of a focused portfolio containing fewer categories of projects. On the contrary, a focused portfolio may trigger a more in-depth utilization and dissemination of projects outcomes by empowering human and physical resources for enabling green innovation process (Chen, et al., 2006; Maylor, et al., 2018; Maylor \& Turner, 2017) and upgrading current technology to a higher level, which can eventually lead to a higher level of projects performance. 
Directing attention to allocate resources towards managing a broad portfolio can be influenced by the institutional pressure. Environment management literature also insights into how the composition of the green projects portfolio may affect efficiency. In particular, the intention to implement a portfolio comprising a broad range of green projects may be triggered by isomorphic institutional pressure from customers (e.g., buying firms) (Delmas \& Toffel, 2008). Consequently, firms with a broad portfolio can be less inclined to exploit projects in depths. Thus, firms may disrupt attention on projects exploitation, which eventually decreases the efficiency of the projects portfolio. To this end, a focused portfolio can yield higher efficiency than a broad portfolio. In sum, we hypothesize that:

Hypothesis 1 (H1): A focused portfolio is associated with greater efficiency than a broad portfolio.

\subsection{Interaction of financial strength and portfolio focus}

There has been well-established literature discussing organizational performance and practice adoption (Chatterji, 2009; Hull \& Rothenberg, 2008; Somech, 2006). These studies argue that firm performance is associated with whether and to what extent they would adopt practices. We extend these notions in the literature to understand whether and how firm's financial strength can interact with portfolio focus to affect portfolio efficiency.

In general, financially stronger firms have more slack resources (e.g., time and money) to invest in a wide range of green projects. Therefore, a focused portfolio may not be able to utilize and exploit resources and managerial attention towards environmental management to the fullest extent. In addition, financially stronger firms tend not to seek for quick solutions concerning a specific aspect of environment management but are more likely to learn and adapt (Wiersma, 2007) by engaging in a wide range of projects since they have adequate resources to leverage and attention to direct. As a result, such firms are able to benefit from a broad portfolio than a focused portfolio. Financially weaker firms, on the other hand, have fewer cushions of 
slack resources. Hence, it is difficult for them to dedicate to a wide range of commitments while exploiting various competing projects. Other studies also argue that low performing firms have lower wherewithal with which to exploit projects and drive projects efficiency (Jacobs, et al., 2015). As such, a focused portfolio is likely to allow for effective exploitation when dedicated resources (e.g., human capital and technologies) and managerial attention are scarcely available. Consequently, financially weaker firms that adopt a focused strategy can be better enabled to improve overall portfolio efficiency. For example, the authors interviewed several suppliers which experienced financial losses when they implemented the green projects. The CEOs and senior managers revealed that it was difficult to allocate sufficient human capital and monetary investment to diagnose pilot green projects in determining which categories of projects are best for the current processes. As such, they tended to adopt a conservative approach, i.e., focusing on a specific area that they deem as most urgent and necessary for improvement, to make changes. This, in turn, created a flexible and effective environmental management system in which they find easier to interpret and apply their existing knowledge stocks and acquire new knowledge as regards to green projects implementations. For these reasons, we provide the following hypothesis to suggest the presence of an interaction effect between a firm's financial strength and the portfolio focus:

Hypothesis 2 (H2): Firm's financial strength weakens the positive relationship between portfolio focus and efficiency, i.e., financially stronger (weaker) firms benefit less (more) from a focused portfolio than financially weaker (stronger) firms.

\subsection{Projects complementarities}

In green project management context, people-related projects aim at enhancing human systems to reinforce people's roles in managing environment through human capital training programs and organizational restructuring (Fahimnia, et al., 2015). In doing so, the people enabled green changes can improve decision-makers' awareness of corporate green goals and know-how in 
implementing such changes. On the other hand, technical systems which concern techniques, tools, and procedures (Closs, et al., 2008) facilitate green projects implementation by enabling firms to continuously improving their internal processes and updating green technologies (Sarkis, et al., 2011).

From a socio-technical systems theoretical perspective, "organizational objectives are best met not by the optimization of the technical system and the adaptation of the social system to it, but by the joint optimization of the technical and social system "(Cherns, 1976). We elaborate how people-related projects (i.e., employee-and management-related improvement) can interact with technical-related (process- and technology-related) projects to positively affect portfolio efficiency as below. Previous literature suggest that human dimensions have not been emphasized as much as technical system in implementing organizational change efforts, thus leading to discrepancies between goals set and actual performance (Hyer, et al., 1999; Liu, et al., 2006). This could be due to the lack of employees' essential skills and codes of conduct for operating the technical system and low commitment to which employees would dedicate to get work done when confronted to the technical system.

On the contrary, a synergy between social and technical systems may create congruence to enhance portfolio efficiency. This is because people-related green projects help educate and train employees to acquire essential knowledge with respect to specific green practices and corporate's ultimate green goals, which is likely to trigger a "social support structure" (Hyer, et al., 1999; Liu, et al., 2006) for green process and technology improvements. For instance, the social support structure consisting of reward systems, know-how to implement green practices, training policies, and conflict- mitigating strategies etc., could act as a complementary resource to facilitate the continuous improvement endeavors by technical system (process-and technology-related projects). The interdependencies between social and technical aspects of green projects may enhance the overall efficiency of a portfolio. In other words, it is expected 
that social green projects deployed to complement technical green projects will increase portfolio efficiency. Hence, we hypothesize that:

Hypothesis 3 (H3): Social green projects (people-related) have a complementary effect with technical green projects (process-and technology-related) which will enhance portfolio efficiency, i.e., the higher the interaction of social and technical green projects, the greater the portfolio efficiency will be.

\section{Research context and data}

The focal buyer firm in this study is one of the top five automotive manufacturers (in terms of global market share, hereafter Apollo). The data of green projects are archived by Apollo and we were able to access the recent three years' (2015-2017) comprehensive project-level data. To ensure the quality of the projects, on average, Apollo greens 30 suppliers every year. The suppliers represent a wide range of manufacturing firms covering the 3-digit U.S. Standard Industry Codes (SICs) of 253 (public building and related furniture), 301(tires and inner tubes), 305 (hose, belting, gaskets, and packing), 323 (products of purchased glass), 344 (fabricated structural metal products,) 346 (metal forgings and stamping), 367 (metal services) and, 371 (motor vehicles and equipment) ${ }^{1}$. The project-level data details the description, category, timespan, investment, performance outcome, etc. variables of each individual project within a portfolio. A supplier may have implemented multiple projects within a portfolio. Therefore, projects are nested in a supplier (portfolio) and all the suppliers are coded with a unique Dun \& Bradstreet number. Consequently, we obtained other firm-level variables from Dun \& Bradstreet company (firm-level variables are detailed in Section 4.2).

Apollo initiated the Greening Supplier Program aiming at providing technical assistance to their first-tier suppliers in China to enhance their green performance (i.e., achieve energy saving and emission reduction goals). Apollo hired an independent third party company (a U.K.

\footnotetext{
${ }^{1}$ The SIC codes are provided by the Dun \& Bradstreet company.
} 
headquartered subsidiary which is operating in China) which has been an expert in providing environmental solutions (technical assistance) and auditing for more than 20 years worldwide. The third party company worked with Apollo to promote and help suppliers implement green projects. Suppliers expected to gain benefits from becoming greener by implementing projects. They agreed to be audited by the third party including disclosing investment amounts and financial transaction records and performance outcomes with regard to their green projects. Specifically, the third party company first assessed a supplier's initial green performance. Later on, the third party passed specific improvement recommendations covering all eight categories (see portfolio focus in Table 2) of green projects to the supplier. The supplier would voluntarily implement projects as they deemed appropriate. Two rounds of assessment (mid-term and final) were conducted in the supplier by the third party. The third party company continuously audited all investments and project outcome data in suppliers. For example, the expenses for purchase and implemented practices were all documented, which were subject to financial audits. All CO2 emission, energy saving (electricity consumption), and natural resource saving (water usage) were checked for the consistency with the archival data provided by the government agency (Chinese central government has authorized all local environmental agencies to track manufacturers' energy/water consumption and greenhouse gas emission. Such records can be publicly available) see Lo, et al. (2018), for example. In consultation with the third party experts, we understood that they had a well-developed algorithm to estimate energy savings and emission reductions by accounting for firms' time-variant dynamics (e.g., change of production capabilities from year to year). Therefore, the green project performance data should be reliable to capture the reductions attributable to the implementation of green projects. Overall, the validated project-level data by the third party and the firm-level data obtained from Dun \& Bradstreet should be able to overcome self-report basis.

\section{$<$ Insert Fig. 1 about here $>$}




\section{Analyses and results}

\subsection{Data envelopment analysis of portfolio efficiency}

The unit of analysis in this study is the portfolio which corresponds to each of the supplier firms in our sample. We examined the overall efficiency of a green project portfolio by employing the Data Envelopment Analysis (DEA). DEA is a mature methodology that has been widely adopted by numerous studies (Ayabakan, et al., 2017; Sarkis, 2000; Sarkis \& Cordeiro, 2001; Swink, et al., 2006). DEA allows us to estimate how efficient a firm can convert inputs (investments) to outputs (performance outcomes) in relative to an efficient frontier by comparing each Decision Making Units (DMU) with only the superior DMU in the group (W. W. Cooper, et al., 2004).

We follow the procedures suggested in the previous empirical research (Sarkis, 2000; Sarkis \& Cordeiro, 2001; Swink, et al., 2006) and take into account the advancements of DEA(Simar \& Wilson, 2007) in recent years to select a suitable DEA model from various available models for our study. Specifically, given that firms in our sample were requested to report multiple inputs and outputs relevant to their green projects, we use the two-stage, multiinput-multi-output DEA model to estimate the efficiency scores of each DMU (i.e., the portfolio in this study). In total, Table 1 lists three inputs, namely, the number of projects, project timespan, and monetary investment and five outputs, namely, reduction of greenhouse gas emission, reduction of solid waste disposal, energy saving, natural resource saving, and cost saving. The number of inputs and outputs meets the "rule of thumb" stating that "the number of DMUs (i.e., 90) be at least twice the number of inputs and outputs combined (i.e., 8)" (Cook, et al., 2014). In order to "preserve the greatest degree of granularity in the analysis" (Swink, et $a l ., 2006)$, we included all inputs and outputs variables as mentioned above. Consistent with Swink, et al. (2006), we used variable returns to scale (VRS) model because "as more resources are invested in a project, the performance outcomes do not improve proportionally". We also 
incorporated the advancement (i.e., the double bootstrap procedure) of DEA, see Simar and Wilson (2007).

\section{$<$ Insert Table 1 about here $>$}

Table 1 gives the operationalization and statistics of the variables. All variables are mean normalized (Sarkis \& Cordeiro, 2001) in order to be compatible with the scale for DEA in $R$ program. We used the output-oriented ("from a DEA modeling point of view, both input and output orientations will yild the same efficient frontier", see Cook, et al. (2014)), return-toscale, and bias-corrected DEA model. A DEA score equaling one means that the portfolio is efficient while a DEA score less than one indicates that the portfolio is inefficient.

\subsection{Portfolio focus, financial strength, and efficiency}

Simar and Wilson (2007) have proposed a robust method which bootstraps efficiency scores with a truncated regression. This method thus could deal with challenges that previous DEA models may not solve, see Barros and Dieke (2008) for these challenges. The dependent variable used in the regression is the efficiency score of a project portfolio obtained from DEA. Table 2 lists the variables and how they are operationalized for regression analysis. We control for firm innovativeness, firm type (public or private), firm size, firm age, investment concentration, ISO 14001 certification to account for their possible impacts on the dependent variable. In addition, industry, region, and year dummy variables are included in all models. Portfolio focus is the independent variable which captures how focused (the reversed ratio between the number of categories implemented within a portfolio and the total number of categories, i.e., 8) a portfolio is. Our interviews with the buying firm and several suppliers confirmed that industrial experts believed that our measurement of portfolio focus would be ideal because it captures the actual number of categories relative to the total recommended eight categories and is less influenced by other firm inherent factors such as size. Note that the eight 
categories of green projects are predetermined by the third party company prior to providing recommendations of specific green projects to the supplier firms. The categorizing is based on the third party company's expertise in environmental management and therefore we follow this to avoid subjective judgment on the categorizing. Financial strength is the interaction variable which measures the degree to which the firm is financially healthy.

\section{$<$ Insert Tables 2, 3 and 4 about here $>$}

In table 4 , the baseline model includes all control variables. The addition of portfolio focus in Model 1 shows a statistically significant positive effect (beta $=0.021, p<0.01$ ), meaning that the more focused a portfolio is, the higher the efficiency will be. Therefore, H1 is supported. In model 3, the interaction of portfolio focus and financial strength is statistically significant and negative (beta $=-0.06, p<0.01$ ), suggesting that financial strength weakens the positive relationship between portfolio focus and efficiency, which is in support of H2. Fig. 2 depicts the interaction between the portfolio focus and financial strength.

\section{$<$ Insert Fig. 2 about here $>$}

\subsection{Complementary analysis}

The projects are divided into eight categories by the third party (see the description of portfolio focus in Table 2). We take cautions to group the eight categories into people-, process-, and technology-related projects. We consulted with the experts in the third party company and other industry professionals and referred to the literature (Closs, et al., 2008; Geels, 2004) to overcome possible biases that could be introduced in grouping them. By the definition of a. employee-related improvement and b. management improvement, we categorize a and $\mathrm{b}$ as people-related since a is associated with human capital improvement and $\mathrm{b}$ is related to restructuring organizations to incorporate green practices. c. material and energy replacement, d. process improvement and optimization, e. recycling, and f. facility improvement and 
transformation are grouped into process-related because all of them involve tasks of improving and creating green processes for optimization and meeting the new standards for environmental management. Finally, g. manufacturing technology improvement and transformation and $h$. product adjustment and change are grouped into technology-related since both of them are innovation-oriented and are enabled by new technology. One example under each of the eight categories is provided in Table 5 .

\section{$<$ Insert Table 5 about here $>$}

The independent variable is the count of people-, process-, and technology- related projects, respectively within a portfolio. Table 6 gives the regression analysis results. Models 1 to 3 separately added people, process, and technology variable, respectively. As can be seen, the people-related project has a negative and significant effect on the efficiency while the process-related project has a positive and significant effect on the efficiency. However, the technology-related project has a negative but insignificant effect. The results of independent variables suggest that there is a discrepancy among the effect of people, process, and technology on the portfolio efficiency. However, the interaction analysis shows that people-related projects interact with process-related projects to enhance the project portfolio efficiency (see Model 4, beta $=0.136, p<0.05)$. Also, people-related projects interact with technology-related projects to positively affect efficiency ( $\operatorname{see}$ Model 5 , beta $=0.055, p<0.01$ ). Process-related projects do not have a significant interaction effect with technology-related projects. In sum, the above results indicate that when implemented together, social (people-related) green projects and technical (process- and technology-related) green projects can display complementary effect and thus help firms to improve green portfolio efficiency. Hence, H3 is supported.

\section{<Insert Table 6 about here $>$}




\section{Robustness checks}

To give a comprehensive view of how different category of project affects efficiency and check the robustness of the results in Table 6, we separately coded each category of project in a portfolio and conducted a series of regression analyses. We added all control variables used in Table 5 in all models (not shown). Table 7 gives the results of the individual category of the project on efficiency. As can be seen, the results are highly consistent with our results of grouped people, process, and technology-related results. For instance, process improvement and transformation (beta $=0.06, p<0.01$ ) and facility improvement and transformation (beta $=0.03, p<0.05)$ both have a statistically significant and positive impact on the efficiency, implying that on average, inducing these two categories in a portfolio help drive the efficiency of the projects portfolio.

\section{<Insert Table 7 about here $>$}

\section{Discussion}

\subsection{Theoretical contribution}

This section discusses the contribution of this study for theory. To begin with, this research used the DEA method to estimate the efficiency of green project portfolio which takes multiple inputs and outputs into account. Evidenced by previous studies (Sarkis, 2000; Sarkis \& Cordeiro, 2001), DEA is considered an effective approach to estimate the return-on-investment for environment management studies. We not only used one-time monetary investment but also time investment and project number as the inputs. Similarly, a variety of environmental performance metrics such as the reduction in emission, solid waste disposal, energy consumption (electricity), water usage along with cost saving were accounted into the model. As such, we developed a comprehensive framework for establishing a green project portfolio and return-on-investment analysis. 
Second, we contribute to the literature of project-driven organizational change effort towards improving green performance. Most previous research looks at projects in isolation, ignoring complexities involved in achieving successful green project portfolio management in firms. In particular, we developed a conceptual framework building on the growing line of research which seeks to understand the emerging approach of managing suppliers' environment performance, i.e., externally promoted change efforts by regulatory agencies (e.g., government) or business partners (e.g., buying firms) to improve social and environment performance (Dhanorkar, et al., 2017; Plambeck \& Taylor, 2015; Porteous, et al., 2015). Along similar lines, this study investigated the efficiency of an increasingly popular means of environmental management, i.e., buyer recommended-supplier voluntarily implemented project-driven organization change efforts (BR-SI-PDE) whereas we found that the change efforts made in the form of project portfolio drive efficiency to a greater extent for a focused than for a broad portfolio. This is a critical finding for environmental management by means of organizational change efforts, suggesting that firms should properly direct their limited managerial attention and resources to implement green initiatives by focusing on a few projects rather than aggressively targeting a broad portfolio in the pursuit of a higher return-on-investment. In other words, in firms' efforts to adapt and develop organizational change towards environmental management, a focused strategy can outperform compared with a broad strategy in achieving intended environmental outcomes.

Third, we tested our theorizing of the moderating role of one critical firm contingency, i.e., financial strength, with the portfolio focus on the portfolio efficiency. The analysis results showed that financially weaker firms are able to better leverage a focused portfolio in attaining a higher efficiency than financially stronger firms, which provided support for our theoretical framework. Specifically, we extend the understanding on the interaction effect of firm's financial strength and portfolio focus on efficiency by showing that a focused portfolio can lead 
to higher efficiency when firms experience an unfavorable than favorable financial circumstance.

Last but not least, we make a contribution to the growing literature on managing distinct projects within a portfolio to achieve intended organizational goals in the context of environmental management. We adopted a socio-technical systems perspective to investigate the complementarities among people-, process-, and technology-related projects. Our results posit that social green projects (people-related) adopted together with a highly technicaloriented green projects (intensive process- and technology-related projects) can display significant complementary effect. We uncovered that it is possible for firms to improve environmental performance through green projects when the social and technical projects are congruent with one another rather than implemented solely. The findings support the logic of complementarities in socio-technical systems theory. Also, scholars may note that the integration of social and technical efforts can significantly enhance project-driven environment performance. On the other hand, the post hoc analysis reveals that when implemented alone, different types of projects drive portfolio efficiency in opposing directions (e.g., implementing employee-related project alone harms the efficiency while process improvement and transformation-related project increases efficiency) or turns out to be a zero-sum game (unproductive) in contributing to the overall efficiency (e.g., recycling-related project alone does not have a significant impact on efficiency). This further suggests that socio-technical conjunction between projects could be a promising approach to achieve high efficiency.

\subsection{Practical contribution}

Our study provides several critical managerial implications. Many multinational buying firms spend millions of dollars developing effective green initiatives to promote practices among their

local suppliers (Forbes, April 22, 2014). To this end, a better understanding of how buying firms could more effectively translate their investments (e.g., providing technical assistance) 
into positive green outcomes in their suppliers can be critical for building a socially responsible supply chain. In the first place, our theoretical framework of the BR-SI-PDE demonstrates a promising mode for greening suppliers. In other words, we believe that the case of Apollo regarding how it coordinates with the third party company to green its suppliers could be a promising starting point for other multinational firms. Specifically, suppliers could be encouraged to participate in such programs where the third party expert hired by the buying firm is able to provide professional technical solutions to environment management (e.g., technical assistance).

The finding suggests that suppliers should select a focused strategy in implementing green projects. A focused green project portfolio is better able to leverage the capability of converting green investments into the intended green outcomes. Therefore, managers should note that in achieving a more efficient green portfolio management, selecting a few categories of projects is recommended rather than including a wide range of categories in the green portfolio. However, portfolio focus-efficiency linkage appears to be dependent on the firm's financial circumstance, meaning that a firm can benefit more from a focused portfolio when the financial strength is low than when it is high. Consequently, financially weak firms could be more urged to carefully formulate a focused portfolio so as to achieve higher efficiency while financially strong firms may be allowed to include a wide range of project categories within a portfolio. Under the regime of the $B R-S I-P D E$, the buying firms and the third party auditor may also need to note that in coordinating with the supplier firms to improve their green performance, a more efficient approach would be to recommend suppliers to create a focused portfolio and take into account financial status.

While the main effect of focused versus broad portfolio and the moderating role of firms' financial status on the portfolio efficiency are noteworthy, another significant managerial implication from this study is in suggesting how to formulate a green portfolio such that one 
type of projects can be complementary to another. Specifically, managers are advised to not only implement social or technical green projects but to combine them within a green portfolio. In particular, in the presence of the social green projects, process- and technology- related projects may manifest better effects than when they are implemented alone. For instance, technical projects alone (process- and technology- related projects) may yield zero-sum game in enhancing portfolio efficiency.

\subsection{Limitations and future research}

Our study was not without limitations and these limitations may offer future research opportunities. Our data was cross-sectional in nature which hindered us to understand how the intervention projects were maintained and followed for making continuous progress in enhancing corporate green performance. In other words, examining the portfolio efficiency using panel data to uncover the longitudinal relationship between investments and performance benefits could be fruitful. In particular, firms should not be satisfied by the improvement in green performance triggered by one-time investment but need to find solutions to sustain their green performance in the long run. We were unable to obtain panel data (the projects in our sample were one-time in nature). However, our research framework and relationships observed in the present study provide a starting point for future research. In the meanwhile, this study mainly focused on suppliers' investments and green performance outcomes while it is also worthwhile to explore how the buying firm was motivated to initiate improvement recommendations for suppliers and the associated costs and benefits for buyer itself. This is critical as hiring the third party company to audit the "greening" process, site visits, and other coordination activities incurred tremendous costs for the buying firm. An effective coordination scheme is yet to be discovered for enabling buying firm to manage suppliers' green performance. Specifically, it would be urgent to empirically validate a coordination strategy that both parties, 
i.e., supplier and buying firm, could exploit the supply chain cost structure in enhancing green performance. 


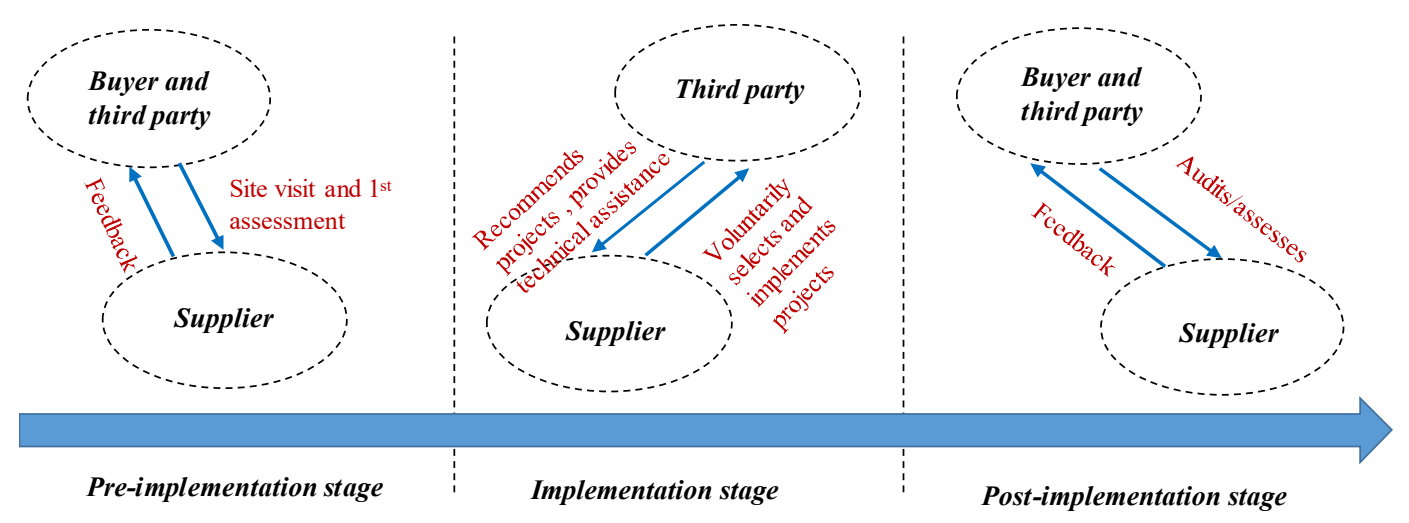

Fig. 1. Green project portfolio implementation context in this study.

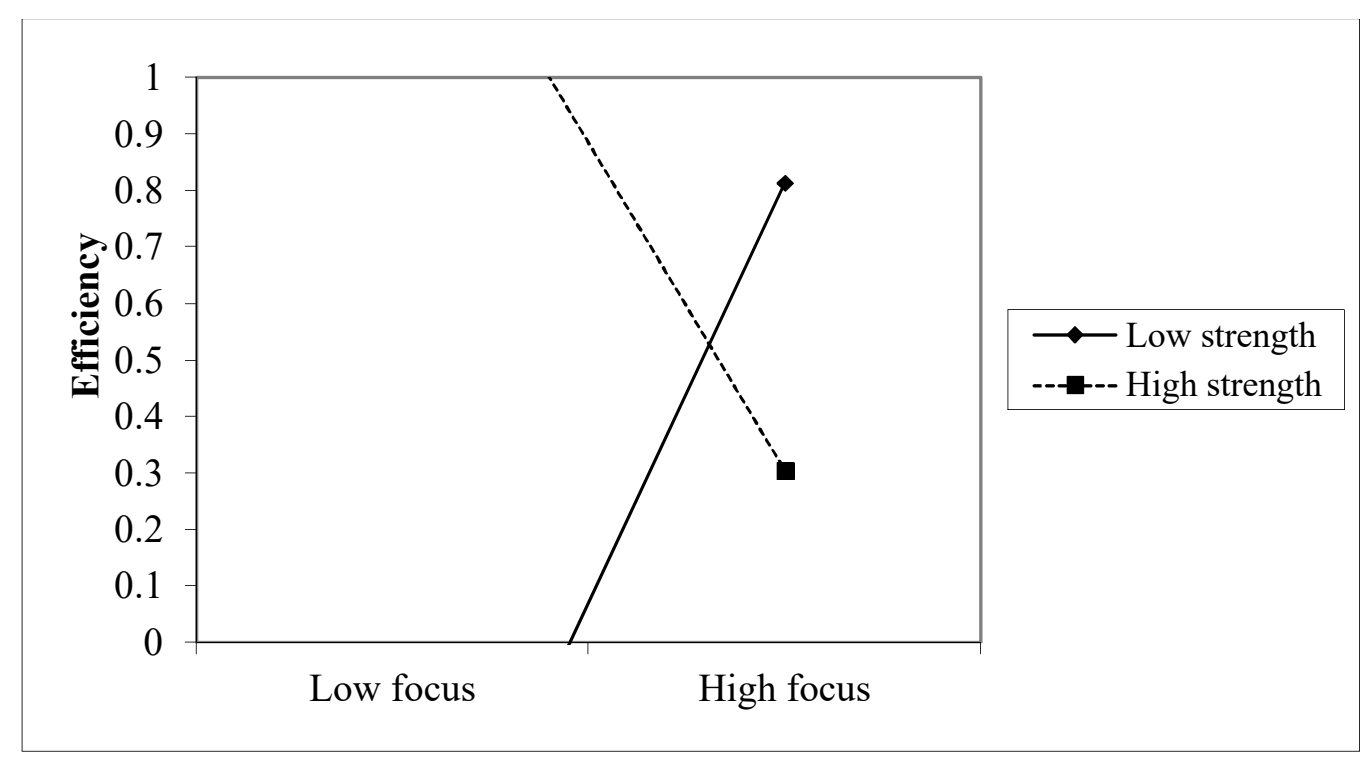

Fig. 2: Moderating effect of firm's financial strength on portfolio efficiency (all other significant variables held constant at means). 
Table 1: Input and output variables for DEA

\begin{tabular}{|c|c|c|c|c|}
\hline Variable & $\begin{array}{l}\text { Input or } \\
\text { output }\end{array}$ & Description & Mean (raw data) & SD (raw data) \\
\hline Number of projects & Input & $\begin{array}{l}\text { Log of the total number of } \\
\text { projects in a firm's } \\
\text { portfolio. }\end{array}$ & 3.59 & 2.15 \\
\hline Project timespan & Input & $\begin{array}{l}\text { Log of the sum of projects } \\
\text { timespan within a firm's } \\
\text { portfolio (in months). It } \\
\text { captures the total time } \\
\text { spent across all projects } \\
\text { within a portfolio. }\end{array}$ & 7.25 & 3.83 \\
\hline Monetary investment & Input & $\begin{array}{l}\text { Log of the sum of } \\
\text { monetary investments of } \\
\text { all projects within a firm's } \\
\text { portfolio (in Chinese } \\
\text { Yuan). }\end{array}$ & $\begin{array}{l}6,527,953.06 \\
(\approx 979,813.11 \\
\text { \$US) }\end{array}$ & $42,728,191.25$ \\
\hline $\begin{array}{l}\text { Reduction of } \\
\text { greenhouse gas } \\
\text { emission }\end{array}$ & Output & $\begin{array}{l}\text { Log of the sum of } \\
\text { reduction of greenhouse } \\
\text { gas, i.e., CO2 ton/year, } \\
\text { from all projects within a } \\
\text { portfolio. }\end{array}$ & 752.99 & 2579.73 \\
\hline $\begin{array}{l}\text { Reduction of solid waste } \\
\text { disposal }\end{array}$ & Output & $\begin{array}{l}\text { Log of the sum of } \\
\text { reduction of solid waste } \\
\text { (ton/year)from all projects } \\
\text { within a portfolio. }\end{array}$ & 93.08 & 609.43 \\
\hline $\begin{array}{l}\text { Energy saving } \\
\text { (electricity) }\end{array}$ & Output & $\begin{array}{l}\text { Log of the sum of } \\
\text { electricity usage reduction } \\
\text { from all projects within a } \\
\text { portfolio (kwh/year). }\end{array}$ & $373,381.33$ & $1,104,958.46$ \\
\hline $\begin{array}{l}\text { Natural resource saving } \\
\text { (water) }\end{array}$ & Output & $\begin{array}{l}\text { Log of the sum of the } \\
\text { water consumption } \\
\text { reduction from all projects } \\
\text { within a portfolio } \\
\text { (ton/year). }\end{array}$ & $4,675.60$ & $14,915.98$ \\
\hline Cost saving & Output & $\begin{array}{l}\text { Log of the sum of } \\
\text { monetary savings resulted } \\
\text { from projects } \\
\text { implementation (in } \\
\text { Chinese Yuan). }\end{array}$ & $\begin{array}{l}1,310,398.026 \\
(\approx 196,684.19 \\
\text { \$US })\end{array}$ & $548,5389.53$ \\
\hline
\end{tabular}

Note. In DEA analysis, all input and output variables are mean normalized in order to be compatible with the scale for analysis in $R$ program. To give an overview of the investments and outputs, means and SDs are raw data before taking any transformation. 
Table 2: Variables for regressions

\begin{tabular}{|c|c|c|c|c|}
\hline Variable & Description & Operationalization & Mean & SD \\
\hline DEA score (DV) & $\begin{array}{l}\text { DEA score from output oriented, } \\
\text { return-to-scale, bias-corrected } \\
\text { Data Envelopment Analysis. }\end{array}$ & $\begin{array}{l}0<\text { DEA score } \leq 1 \\
\text { (inefficient if DEA score is } \\
\text { smaller than } 1 \text { ) }\end{array}$ & 0.84 & 0.07 \\
\hline Portfolio focus & $\begin{array}{l}\text { It captures how a portfolio } \\
\text { focuses on one or several specific } \\
\text { type(s) of projects from the } \\
\text { predetermined eight categories of } \\
\text { projects. The recommended eight } \\
\text { categories of green projects by } \\
\text { the third party auditor include a) } \\
\text { employee-related improvement; } \\
\text { b) management improvement; c) } \\
\text { green material/energy } \\
\text { replacement; d) process } \\
\text { improvement and optimization; e) } \\
\text { recycling; f) manufacturing } \\
\text { technology improvement and } \\
\text { transformation; g) facility } \\
\text { improvement and transformation; } \\
\text { h) product adjustments and } \\
\text { changes. }\end{array}$ & $\begin{array}{l}\text { The reversed ratio between } \\
\text { the counts of different } \\
\text { categories of projects } \\
\text { adopted in a portfolio and } \\
\text { the total number of the } \\
\text { recommended project } \\
\text { categories, i.e., eight. For } \\
\text { example, if a portfolio } \\
\text { contains a, c, and f } \\
\text { categories (three different } \\
\text { categories in total), then it } \\
\text { is calculated as the reverse } \\
\text { value of } 3 / 8=0.375 \text {, i.e., - } \\
0.375\end{array}$ & -0.74 & 0.27 \\
\hline $\begin{array}{l}\text { Investment } \\
\text { concentration }\end{array}$ & $\begin{array}{l}\text { The concentration of the efforts } \\
\text { made to enhance a specific } \\
\text { project in a portfolio. It measures } \\
\text { whether efforts (investments) are } \\
\text { allocated equally among all } \\
\text { projects or skewed a specific } \\
\text { project. }\end{array}$ & $\begin{array}{l}\text { The Herfindahl- } \\
\text { Hirschman Index (HHI) of } \\
\text { the investment share } \\
\text { among all projects, i.e., } \\
\text { sum of the squared values } \\
\text { of the investment per } \\
\text { project divided by the total } \\
\text { investments to a portfolio. }\end{array}$ & 0.70 & 0.24 \\
\hline Firm innovativeness & $\begin{array}{l}\text { Cumulative innovativeness of a } \\
\text { firm. }\end{array}$ & $\begin{array}{l}\text { Logarithm of the counts of } \\
\text { the total patents obtained } \\
\text { till the focal year, i.e., } \\
\text { green project } \\
\text { implementation year. }\end{array}$ & 1.58 & 1.90 \\
\hline Firm financial strength & $\begin{array}{l}\text { Dun \& Bradstreet's assessment } \\
\text { on firm's "dollar-weighted } \\
\text { numerical indicator of how a firm } \\
\text { paid its bills over the past year, } \\
\text { based on trade experiences } \\
\text { reported to D \& B by various } \\
\text { vendors". It has been widely used } \\
\text { in previous studies (e.g., Levine } \\
\text { \& Toffel, 2010). }\end{array}$ & $\begin{array}{l}\text { Data available is } \\
\text { categorical based on five } \\
\text { levels: Strong (4), Good } \\
(3), \text { Fair (2), Poor (1), and } \\
\text { Risky (0). It is the firm } \\
\text { financial strength indicator } \\
\text { released in the focal year } \\
\text { of green projects } \\
\text { implementation. }\end{array}$ & 3.11 & 1.45 \\
\hline
\end{tabular}




\begin{tabular}{|l|l|l|l|l|}
\hline Public firm? & $\begin{array}{l}\text { It indicates whether a firm is } \\
\text { listed in the stock market when } \\
\text { implementing the green projects. } \\
\text { Publicly-traded firms may be } \\
\text { exposed to more intensive } \\
\text { screening and institutional } \\
\text { pressures. }\end{array}$ & $\begin{array}{l}\text { Binary variable taking a } \\
\text { value of 1 if listed, 0 } \\
\text { otherwise. }\end{array}$ & 0.04 & 1.50 \\
& $\begin{array}{l}\text { Firm scale in terms of the total } \\
\text { number of employees. }\end{array}$ & $\begin{array}{l}\text { Log of the total number of } \\
\text { employees in the year } \\
\text { when green projects were } \\
\text { implemented. }\end{array}$ & 6.26 & 1.27 \\
\hline Firm size & $\begin{array}{l}\text { It measures how long the firm } \\
\text { has been established. D \& B has } \\
\text { access to this information from } \\
\text { the Department of Commerce. } \\
\text { years between the year } \\
\text { established and the focal } \\
\text { year when the green } \\
\text { projects were } \\
\text { implemented. }\end{array}$ & 2.28 & 0.65 \\
\hline ISO 14001 certified? & $\begin{array}{l}\text { Whether ISO 14001 certification } \\
\text { was obtained prior to the focal } \\
\text { year of green projects } \\
\text { implementation. }\end{array}$ & $\begin{array}{l}\text { Binary variable taking a } \\
\text { value of 1 if obtained, } 0 \\
\text { otherwise. }\end{array}$ & 0.39 & 0.49 \\
\hline
\end{tabular}


Table 3: Correlation matrix

\begin{tabular}{|c|c|c|c|c|c|c|c|c|c|c|c|c|c|c|}
\hline & Variable & VIF & 1 & 2 & 3 & 4 & 5 & 6 & 7 & 8 & 9 & 10 & 11 & 12 \\
\hline 1 & DEA score & & 1 & & & & & & & & & & & \\
\hline 2 & Portfolio focus & 2.45 & 0.0059 & 1 & & & & & & & & & & \\
\hline 3 & Financial strength & 2.21 & 0.2843 & -0.0583 & 1 & & & & & & & & & \\
\hline 4 & Innovativeness & 2.21 & 0.1425 & -0.1618 & 0.41 & 1 & & & & & & & & \\
\hline 5 & $\begin{array}{l}\text { Investment } \\
\text { concentration }\end{array}$ & 1.98 & -0.0146 & 0.1083 & -0.0383 & -0.187 & 1 & & & & & & & \\
\hline 6 & Public firm & 1.54 & 0.1551 & -0.1632 & 0.2827 & 0.4149 & 0.0644 & 1 & & & & & & \\
\hline 7 & Firm size & 1.51 & 0.3689 & -0.131 & 0.4819 & 0.5599 & -0.0649 & 0.4254 & 1 & & & & & \\
\hline 8 & Firm age & 1.45 & 0.2511 & -0.1776 & 0.4356 & 0.6672 & -0.1198 & 0.2433 & 0.6541 & 1 & & & & \\
\hline 9 & $\begin{array}{l}\text { ISO14001 } \\
\text { certified }\end{array}$ & 1.40 & 0.1958 & 0.0417 & 0.1599 & 0.0758 & 0.0314 & 0.1598 & 0.2371 & 0.1576 & 1 & & & \\
\hline 10 & People & 1.17 & -0.2751 & -0.4826 & -0.0352 & 0.0225 & 0.0317 & -0.0285 & 0.015 & 0.0456 & -0.093 & 1 & & \\
\hline 11 & Process & 1.11 & 0.4332 & 0.033 & 0.1685 & 0.0484 & -0.0306 & 0.0325 & 0.1537 & 0.1145 & 0.1203 & -0.2243 & 1 & \\
\hline 12 & Technology & 1.09 & -0.1504 & -0.4774 & -0.0191 & 0.0552 & -0.0511 & 0.1431 & -0.0126 & -0.021 & -0.1282 & 0.0572 & -0.1764 & 1 \\
\hline
\end{tabular}


Table 4: Portfolio focus and financial strength on efficiency

\begin{tabular}{|c|c|c|c|c|}
\hline & Baseline & Model 1 & Model 2 & Model 3 \\
\hline \multicolumn{5}{|l|}{ Variable } \\
\hline \multirow[t]{2}{*}{ Portfolio focus } & & $0.0217^{* *}$ & $0.0203 * *$ & $0.0815^{* * *}$ \\
\hline & & $(0.00891)$ & $(0.00879)$ & $(0.0172)$ \\
\hline \multirow[t]{2}{*}{ Firm financial strength } & & & 0.0250 & $0.407 * * *$ \\
\hline & & & $(0.0187)$ & $(0.0939)$ \\
\hline \multirow[t]{2}{*}{ Focus $\times$ financial strength } & & & & $-0.0661 * * *$ \\
\hline & & & & $(0.0161)$ \\
\hline \multirow[t]{2}{*}{ Firm innovativeness } & -0.00572 & -0.00796 & -0.0100 & -0.00671 \\
\hline & $(0.0114)$ & $(0.0108)$ & $(0.0107)$ & $(0.00964)$ \\
\hline \multirow[t]{2}{*}{ Investment concentration } & 0.0137 & 0.0157 & 0.0134 & 0.0191 \\
\hline & $(0.0232)$ & $(0.0225)$ & $(0.0227)$ & $(0.0209)$ \\
\hline \multirow[t]{2}{*}{ Public firm? } & 0.0712 & 0.0446 & 0.0429 & $0.131 * * *$ \\
\hline & $(0.0516)$ & $(0.0477)$ & $(0.0497)$ & $(0.0492)$ \\
\hline \multirow[t]{2}{*}{ Firm size } & 0.0303 & 0.0297 & 0.0259 & 0.0371 \\
\hline & $(0.0255)$ & $(0.0255)$ & $(0.0258)$ & $(0.0234)$ \\
\hline \multirow[t]{2}{*}{ Firm age } & 0.0190 & 0.00198 & 0.000664 & $-1.92 \mathrm{e}-05$ \\
\hline & $(0.0207)$ & $(0.0203)$ & $(0.0203)$ & $(0.0184)$ \\
\hline \multirow[t]{2}{*}{ ISO 14001 certified? } & 0.0132 & 0.00635 & 0.00327 & 0.00591 \\
\hline & $(0.0169)$ & $(0.0162)$ & $(0.0162)$ & $(0.0148)$ \\
\hline \multirow[t]{2}{*}{ Constant } & $0.929 * * *$ & $0.842 * * *$ & $0.817 * * *$ & $0.477 * * *$ \\
\hline & $(0.134)$ & $(0.126)$ & $(0.128)$ & $(0.141)$ \\
\hline Industry dummies & Yes & Yes & Yes & Yes \\
\hline Region dummies & Yes & Yes & Yes & Yes \\
\hline Year dummies & Yes & Yes & Yes & Yes \\
\hline Observations (portfolios) & 90 & 90 & 90 & 90 \\
\hline Observations (projects) & 323 & 323 & 323 & 323 \\
\hline Wald chi-squared & 31.22 & 40.68 & 45.19 & 72.89 \\
\hline Prob $>$ chi-squared & 0.35 & $0.09 *$ & $0.04 * *$ & $0.00 * * *$ \\
\hline
\end{tabular}

Simar \& Wilson (2007) effect analysis; standard errors in parentheses; $0<$ DEA score $\leq \overrightarrow{1}$ (inefficient if DEA score $<1$ ) ; *** $p<0.01$, ** $p<0.05, * p<0.1$; Number of bootstrap replications $=1000$ in all regressions. Additional tests are conducted to ensure that the addition of interaction terms will increase the likelihoods of the estimated models in models 2 and 3 when compared with the likelihoods of their corresponding main effect models, thereby suggesting a statistically significant interaction (complimentary) effect in theses models. 
Table 5: Project details under different categories

\begin{tabular}{|c|c|c|}
\hline Category & $\begin{array}{l}\text { Socio- } \\
\text { technical } \\
\text { perspective }\end{array}$ & Example \\
\hline $\begin{array}{l}\text { a) Employee- } \\
\text { related } \\
\text { improvement }\end{array}$ & People & $\begin{array}{l}\text { "Carried out training with the theme of energy saving and emission } \\
\text { reduction; reward employees with outstanding performance in energy } \\
\text { conservation and emission reduction every month to create a } \\
\text { motivating atmosphere for energy saving and emission reduction." }\end{array}$ \\
\hline $\begin{array}{l}\text { b) Management } \\
\text { improvement }\end{array}$ & People & $\begin{array}{l}\text { "formed a team working on energy conservation and emission } \\
\text { reduction, with team members from Departments of production, } \\
\text { equipment, quality management, EHS, marketing, and accounting. } \\
\text { Each department member takes turns to be the team leader every } \\
\text { week and reports on green performance at weekly meetings" }\end{array}$ \\
\hline $\begin{array}{l}\text { c) Green } \\
\text { material/energy } \\
\text { replacement }\end{array}$ & Process & $\begin{array}{l}\text { "Replaced hydrochloric acid medicament with an environmentally } \\
\text { friendly medicament to wash pipe. Tested the wastewater generated } \\
\text { from washing the pipe with new medicament and test results passed } \\
\text { the non-hazardous standard" }\end{array}$ \\
\hline $\begin{array}{l}\text { d) Process } \\
\text { improvement and } \\
\text { optimization }\end{array}$ & Process & $\begin{array}{l}\text { "Added a computer-controlled circulating water tank to the rotary } \\
\text { welding machine. The water from the tank can be used to } \\
\text { continuously cool the pipes through the spray pipe, which helped } \\
\text { significantly save water consumption" }\end{array}$ \\
\hline e) Recycling & Process & $\begin{array}{l}\text { "Recycled plastic cloths for placing steel coil by cutting them into } \\
\text { smaller pieces for the second plants to reduce the cloth input" }\end{array}$ \\
\hline $\begin{array}{l}\text { f) Facility } \\
\text { improvement and } \\
\text { transformation }\end{array}$ & Process & $\begin{array}{l}\text { "Wrapped the exhaust passage with insulation to reduce the heat loss } \\
\text { and reduce natural gas consumption" }\end{array}$ \\
\hline $\begin{array}{l}\text { g)Manufacturing } \\
\text { technology } \\
\text { improvement and } \\
\text { transformation }\end{array}$ & Technology & $\begin{array}{l}\text { "Introduced air compressor frequency conversion technology to } \\
\text { reduce energy consumption in the production line; adjusted all } \\
\text { subsequent processes in order to be compatible with the newly } \\
\text { adopted technology" }\end{array}$ \\
\hline $\begin{array}{l}\text { h) Product } \\
\text { adjustments and } \\
\text { changes. }\end{array}$ & Technology & $\begin{array}{l}\text { "Gradually abandoned the development and production of non- } \\
\text { environmental cushions and expanded the production capacity of } \\
\text { environmentally-friendly cushions" }\end{array}$ \\
\hline
\end{tabular}


Table 6: Regression of people-, process-, and technology-related projects on efficiency.

\begin{tabular}{|c|c|c|c|c|c|c|}
\hline & Model 1 & Model 2 & Model 3 & Model 4 & Model 5 & Model 6 \\
\hline \multicolumn{7}{|l|}{ Variable } \\
\hline \multirow[t]{2}{*}{ People } & $-0.0722 * * *$ & & & $-0.167 * * *$ & $-0.107 * * *$ & \\
\hline & $(0.0158)$ & & & $(0.0525)$ & $(0.0152)$ & \\
\hline \multirow[t]{2}{*}{ Process } & & $0.190 * * *$ & & $0.0142 * *$ & & $0.196 * * *$ \\
\hline & & $(0.0439)$ & & $(0.00623)$ & & $(0.0465)$ \\
\hline \multirow[t]{2}{*}{ Technology } & & & -0.00442 & & $-0.0237^{*}$ & 0.00708 \\
\hline & & & $(0.0166)$ & & $(0.0139)$ & $(0.0173)$ \\
\hline \multirow[t]{2}{*}{ People $\times$ Process } & & & & $0.136 * *$ & & \\
\hline & & & & $(0.0602)$ & & \\
\hline \multirow[t]{2}{*}{ People $\times$ Technology } & & & & & $0.0558 * * *$ & \\
\hline & & & & & $(0.0111)$ & \\
\hline \multirow[t]{2}{*}{ Process $\times$ Technology } & & & & & & -0.00149 \\
\hline & & & & & & $(0.00294)$ \\
\hline \multirow[t]{2}{*}{ Firm innovativeness } & -0.00773 & -0.00152 & -0.00830 & -0.00247 & $-0.0169 *$ & -0.000411 \\
\hline & $(0.00968)$ & $(0.00999)$ & $(0.0105)$ & $(0.00983)$ & $(0.00870)$ & $(0.00977)$ \\
\hline \multirow[t]{2}{*}{ Investment concentration } & 0.0207 & 0.0255 & 0.0204 & $0.0442 * *$ & $0.0306^{*}$ & 0.0256 \\
\hline & $(0.0205)$ & $(0.0206)$ & $(0.0229)$ & $(0.0220)$ & $(0.0183)$ & $(0.0208)$ \\
\hline \multirow[t]{2}{*}{ Public firm? } & 0.0342 & 0.0447 & 0.0355 & 0.0121 & 0.0541 & 0.0401 \\
\hline & $(0.0435)$ & $(0.0431)$ & $(0.0480)$ & $(0.0417)$ & $(0.0380)$ & $(0.0427)$ \\
\hline \multirow[t]{2}{*}{ Firm size } & $0.0216 * * *$ & $0.0179 * *$ & $0.0216^{* *}$ & $0.0213 * * *$ & $0.0151 * *$ & $0.0187 * *$ \\
\hline & $(0.00805)$ & $(0.00782)$ & $(0.00917)$ & $(0.00759)$ & $(0.00724)$ & $(0.00793)$ \\
\hline \multirow[t]{2}{*}{ Firm age } & 0.00187 & -0.00679 & 0.00220 & 0.00195 & 0.0197 & -0.00799 \\
\hline & $(0.0186)$ & $(0.0186)$ & $(0.0211)$ & $(0.0176)$ & $(0.0161)$ & $(0.0195)$ \\
\hline \multirow[t]{2}{*}{ ISO 14001certified? } & -0.000550 & 0.00110 & 0.00605 & -0.00411 & 0.00153 & 0.000485 \\
\hline & $(0.0145)$ & $(0.0151)$ & $(0.0162)$ & $(0.0139)$ & $(0.0130)$ & $(0.0149)$ \\
\hline Industry dummies & Yes & Yes & Yes & Yes & Yes & Yes \\
\hline Region dummies & Yes & Yes & Yes & Yes & Yes & Yes \\
\hline Year dummies & Yes & Yes & Yes & Yes & Yes & Yes \\
\hline \multirow[t]{2}{*}{ Constant } & $0.828 * * *$ & $0.579 * * *$ & $0.764 * * *$ & $0.913 * * *$ & $0.867 * * *$ & $0.571 * * *$ \\
\hline & $(0.0974)$ & $(0.0868)$ & $(0.0978)$ & $(0.0912)$ & $(0.0714)$ & $(0.0931)$ \\
\hline Observations (portfolio) & 90 & 90 & 90 & 90 & 90 & 90 \\
\hline Observations (projects) & 323 & 323 & 323 & 323 & 323 & 323 \\
\hline Wald chi-squared & $70.00 * * *$ & $77.69 * * *$ & $41.86^{*}$ & $79.24 * * *$ & $116.86^{* * *}$ & $69.51 * * *$ \\
\hline Prob $>$ chi-squared & 0.00 & 0.00 & 0.07 & 0.00 & 0.00 & 0.00 \\
\hline
\end{tabular}


Simar \& Wilson (2007) effect analysis; standard errors in parentheses; $0<$ DEA score $\leq 1$ (inefficient if DEA score $<1$ );

$* * * p<0.01, * * p<0.05, * p<0.1$; Number of bootstrap replications $=1000$ in all regressions. Additional tests are conducted to ensure that the addition of interaction terms will increase the likelihoods of the estimated models in models 4 and 5 when compared with the likelihoods of their corresponding main effect models, thereby suggesting a statistically significant interaction (complimentary) effect in theses models. All IVs and interactions are counts of the number of certain category of project under "people",

"process", and "technology". Coding of the three categories is listed below.

Table 7: How different category of green projects affects portfolio efficiency.

\begin{tabular}{|c|c|c|c|c|c|c|c|c|c|c|}
\hline Variable & Socio-tech & Model a & Model b & Model c & Model d & Model e & Model f & Model g & Model h & Full model \\
\hline \multirow{2}{*}{ Employee-related improvement } & People & $-0.101 * * *$ & & & & & & & & $-0.108 * * *$ \\
\hline & & $(0.0223)$ & & & & & & & & $(0.0196)$ \\
\hline \multirow[t]{2}{*}{ Management improvement } & People & & $-0.0426 * *$ & & & & & & & $-0.0357 * *$ \\
\hline & & & $(0.0212)$ & & & & & & & $(0.0167)$ \\
\hline \multirow[t]{2}{*}{ Material/energy replacement } & Process & & & -0.0202 & & & & & & 0.0234 \\
\hline & & & & $(0.0198)$ & & & & & & $(0.0173)$ \\
\hline \multirow[t]{2}{*}{ Process improvement and transformation } & Process & & & & $0.0416^{* * *}$ & & & & & $0.0617 * * *$ \\
\hline & & & & & $(0.0151)$ & & & & & $(0.0144)$ \\
\hline \multirow[t]{2}{*}{ Recycling } & Process & & & & & 0.0152 & & & & 0.0229 \\
\hline & & & & & & $(0.0200)$ & & & & $(0.0162)$ \\
\hline \multirow[t]{2}{*}{ Facility improvement and transformation } & Process & & & & & & 0.0124 & & & $0.0340 * *$ \\
\hline & & & & & & & $(0.0168)$ & & & $(0.0152)$ \\
\hline \multirow[t]{2}{*}{ Product adjustments and changes } & Technology & & & & & & & 0.0231 & & 0.0172 \\
\hline & & & & & & & & $(0.0498)$ & & $(0.0383)$ \\
\hline \multirow{2}{*}{$\begin{array}{l}\text { Manufacturing technology improvement and } \\
\text { transformation }\end{array}$} & Technology & & & & & & & & -0.0202 & -0.00360 \\
\hline & & & & & & & & & $(0.0163)$ & $(0.0133)$ \\
\hline \multirow[t]{2}{*}{ Constant } & & $0.843 * * *$ & $0.878^{* * *}$ & $0.866 * * *$ & $0.837 * * *$ & $0.844 * * *$ & $0.832 * * *$ & $0.852 * * *$ & $0.882 * * *$ & $0.789 * * *$ \\
\hline & & $(0.0854)$ & $(0.0989)$ & $(0.105)$ & $(0.0955)$ & $(0.106)$ & $(0.105)$ & $(0.103)$ & $(0.102)$ & $(0.0812)$ \\
\hline Wald chi-squared & & $57.29 * * *$ & $39.81 *$ & 33.94 & $43.64 * *$ & 29.68 & 33.48 & 36.95 & 34.32 & $117.38 * * *$ \\
\hline Prob > chi-squared & & 0.00 & 0.04 & 0.14 & 0.02 & 0.28 & 0.15 & 0.08 & 0.13 & 0.00 \\
\hline
\end{tabular}

Simar \& Wilson (2007) effect analysis; standard errors in parentheses; $0<$ DEA score $\leq 1$ (inefficient if DEA score $<1$ ) ; *** $p<0.01, * * p<0.05, * p<0.1 ;$ Number of

bootstrap replications $=1000$ in all regressions. 90 portfolios and 323 projects are analyzed in all models. Control variables are not shown. 


\section{Appendix}

Table A: Details of interviews and data validations

\begin{tabular}{|c|c|c|c|c|}
\hline Interviewee & $\begin{array}{l}\text { Understanding } \\
B R-S I-P D E \\
\text { program in Apollo }\end{array}$ & $\begin{array}{l}\text { Data } \\
\text { interpretation \& } \\
\text { variable } \\
\text { construction }\end{array}$ & $\begin{array}{l}\text { Theoretical } \\
\text { development }\end{array}$ & $\begin{array}{l}\text { Drawing } \\
\text { implications }\end{array}$ \\
\hline $\begin{array}{l}\text { Sustainable operations } \\
\text { managers from the } \\
\text { focal buyer firm Apollo } \\
\text { (two senior managers } \\
\text { who have more than } \\
\text { ten-year working } \\
\text { experience at the focal } \\
\text { firm); } \\
\text { Roles: contacting } \\
\text { suppliers and the third- } \\
\text { party auditor and } \\
\text { reporting project } \\
\text { outcomes to the CEO } \\
\text { and stakeholders }\end{array}$ & $\begin{array}{l}\text { One semi- } \\
\text { structured } \\
\text { interview and one } \\
\text { unstructured } \\
\text { interview: } \\
\text { Asked questions } \\
\text { about the originality } \\
\text { of this program, } \\
\text { funding, challenges, } \\
\text { collaborations with } \\
\text { different parties, } \\
\text { data quality, and } \\
\text { potential data } \\
\text { obtainability for } \\
\text { research }\end{array}$ & $\begin{array}{l}\text { Two semi- } \\
\text { structured } \\
\text { interviews: } \\
\text { Discussed data } \\
\text { structure, } \\
\text { variable names } \\
\text { and meanings, } \\
\text { and how the data } \\
\text { were collected } \\
\text { maintained. }\end{array}$ & $\begin{array}{l}\text { One semi- } \\
\text { structured } \\
\text { interview: } \\
\text { Discussed } \\
\text { implementation } \\
\text { issues in } \\
\text { suppliers and } \\
\text { feedback from } \\
\text { suppliers. }\end{array}$ & 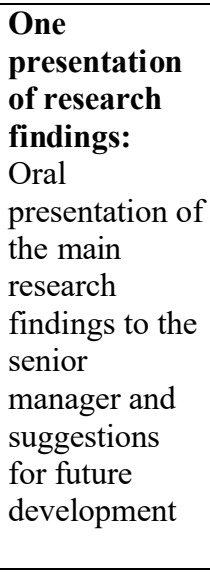 \\
\hline $\begin{array}{l}\text { Environmental Health } \\
\text { and Safety (EHS) } \\
\text { manager and quality } \\
\text { manager (Supplier A); } \\
\text { Roles: facilitating the } \\
\text { on-site visits by Apollo } \\
\text { and the third party } \\
\text { auditor; interpreting } \\
\text { reports of project } \\
\text { recommendation and } \\
\text { writing reports to CEO }\end{array}$ & \multirow[t]{3}{*}{$\begin{array}{l}\text { One semi- } \\
\text { structured } \\
\text { interview at } \mathbf{A}, \mathbf{B} \text {, } \\
\text { and } \mathbf{C}, \\
\text { respectively: } \\
\text { Discussed obstacles, } \\
\text { achievements, and } \\
\text { suggestions } \\
\text { regarding the green } \\
\text { project program. }\end{array}$} & & \multirow[t]{3}{*}{$\begin{array}{l}\text { One semi- } \\
\text { structured } \\
\text { interview at } \\
\text { A, B, and C, } \\
\text { respectively: } \\
\text { Discussed } \\
\text { project } \\
\text { categories, } \\
\text { implementation } \\
\text { challenges, and } \\
\text { portfolio } \\
\text { efficiency }\end{array}$} & \\
\hline $\begin{array}{l}\text { CEO and operations } \\
\text { manager (Supplier B); } \\
\text { Roles: Same with } \\
\text { Supplier A }\end{array}$ & & & & $\begin{array}{l}\text { Presentation } \\
\text { of research } \\
\text { findings: } \\
\text { Oral } \\
\text { presentation of } \\
\text { main research } \\
\text { findings to the } \\
\text { senior } \\
\text { manager and } \\
\text { suggestions } \\
\text { for future } \\
\text { development }\end{array}$ \\
\hline $\begin{array}{l}\text { External relation } \\
\text { manager (Supplier C); } \\
\text { Roles: Same with } \\
\text { Supplier A }\end{array}$ & & & & \\
\hline $\begin{array}{l}\text { Consultants in the } \\
\text { third-party auditor; } \\
\text { Roles: } \\
\text { Coordinating with } \\
\text { Apollo and all } \\
\text { participating suppliers } \\
\text { to help firms } \\
\text { successfully carry out } \\
\text { green projects and } \\
\end{array}$ & $\begin{array}{l}\text { One semi- } \\
\text { structured } \\
\text { interview: } \\
\text { Discussed data } \\
\text { collection process, } \\
\text { data reliability, } \\
\text { Apollo and } \\
\text { participating }\end{array}$ & $\begin{array}{l}\text { One semi- } \\
\text { structured } \\
\text { interview: } \\
\text { Clarified } \\
\text { confusions about } \\
\text { the meaning of } \\
\text { data }\end{array}$ & & \\
\hline
\end{tabular}




\begin{tabular}{|l|l|l|l|l|}
\hline $\begin{array}{l}\text { record projects } \\
\text { performance metrics }\end{array}$ & $\begin{array}{l}\text { suppliers' } \\
\text { motivations }\end{array}$ & & \\
\hline $\begin{array}{l}\text { Data sales consultant } \\
\text { and data scientist in }\end{array}$ & & $\begin{array}{l}\text { Three semi- } \\
\text { structured } \\
\text { Dun \& Bradstreet: }\end{array}$ & $\begin{array}{l}\text { interviews: } \\
\text { Discussed data } \\
\text { Roles: }\end{array}$ & \\
Consulting and selling & & sources/reliability & & \\
firm-level data; & of data & & \\
maintaining and & & & \\
monitoring firm & & & \\
financial data & & & \\
& & & \\
\hline
\end{tabular}

All interviews were conducted at the buyer (Apollo)/supplier/consulting firm sites (face-to-face), on average, each interview lasted about one hour. All individual interviewees were involved in the green projects program (except for the D \& B employees). Additional follow-up phone calls/email communications were also made to clarify confusions. Total timespan for the interviews was 15 months.

\section{References:}

A Watershed Moment, Inside Microsoft's smartest, greenest office yet. https://news.microsoft.com/stories/microsoft-silicon-valley. Last accessed on $30 \mathrm{July,} 2018$.

Aaltonen, K., \& Turkulainen, V. (2018). Creating relational capital through socialization in project alliances. International Journal of Operations \& Production Management, 38(6), 1387-1421.

Anderson Jr, E. G., \& Parker, G. G. (2013). Integration and cospecialization of emerging complementary technologies by startups. Production and Operations Management, 22(6), 1356-1373.

Ayabakan, S., Bardhan, I. R., \& Zheng, Z. E. (2017). AData ENVELOPMENT ANALYSIS APPROACH TO ESTIMATE IT-ENABLED PRODUCTION CAPABILITY. Age, 2, 1.183.

Barros, C. P., \& Dieke, P. U. C. (2008). Measuring the economic efficiency of airports: A SimarWilson methodology analysis. Transportation Research Part E: Logistics and Transportation Review, 44(6), 1039-1051. doi: https://doi.org/10.1016/j.tre.2008.01.001

Battilana, J., \& Casciaro, T. (2012). Change agents, networks, and institutions: A contingency theory of organizational change. Academy of Management Journal, 55(2), 381-398.

Bendoly, E., Bharadwaj, A., \& Bharadwaj, S. (2012). Complementary drivers of new product development performance: Cross-functional coordination, information system capability, and intelligence quality. Production and Operations Management, 21(4), 653-667.

Chao, R. O., Kavadias, S., \& Gaimon, C. (2009). Revenue driven resource allocation: Funding authority, incentives, and new product development portfolio management. Management Science, 55(9), 1556-1569.

Chatterji, A. K. (2009). Spawned with a silver spoon? Entrepreneurial performance and innovation in the medical device industry. Strategic Management Journal, 30(2), 185-206.

Chen, Y.-S., Lai, S.-B., \& Wen, C.-T. (2006). The influence of green innovation performance on corporate advantage in Taiwan. Journal of business ethics, 67(4), 331-339.

Cherns, A. (1976). The principles of sociotechnical design. Human relations, 29(8), 783-792.

Closs, D. J., Jacobs, M. A., Swink, M., \& Webb, G. S. (2008). Toward a theory of competencies for the management of product complexity: six case studies. Journal of Operations Management, 26(5), 590-610.

Cook, W. D., Tone, K., \& Zhu, J. (2014). Data envelopment analysis: Prior to choosing a model. Omega, 44, 1-4.

Cooper, R. G., Edgett, S. J., \& Kleinschmidt, E. J. (2006). Portfolio Management for New Product Development. 
Cooper, W. W., Seiford, L. M., \& Zhu, J. (2004). Data envelopment analysis Handbook on data envelopment analysis (pp. 1-39): Springer.

Criscuolo, P., Dahlander, L., Grohsjean, T., \& Salter, A. (2017). Evaluating novelty: The role of panels in the selection of R\&D projects. Academy of Management Journal, 60(2), 433-460.

Delmas, M. A., \& Toffel, M. W. (2008). Organizational responses to environmental demands: Opening the black box. Strategic Management Journal, 29(10), 1027-1055.

Dhanorkar, S. S., Siemsen, E., \& Linderman, K. W. (2017). Promoting change from the outside: Directing managerial attention in the implementation of environmental improvements. Management Science.

Eriksson, P. E. (2013). Exploration and exploitation in project-based organizations: Development and diffusion of knowledge at different organizational levels in construction companies. International Journal of Project Management, 31(3), 333-341. doi: https://doi.org/10.1016/j.ijproman.2012.07.005

Fahimnia, B., Sarkis, J., \& Davarzani, H. (2015). Green supply chain management: A review and bibliometric analysis. International Journal of Production Economics, 162, 101-114.

Geels, F. W. (2004). From sectoral systems of innovation to socio-technical systems: Insights about dynamics and change from sociology and institutional theory. Research policy, 33(6-7), 897920.

Glaser, V. L. (2017). Design performances: How organizations inscribe artifacts to change routines. Academy of Management Journal, 60(6), 2126-2154.

Greve, H. R. (1998). Performance, aspirations, and risky organizational change. Administrative Science Quarterly, 58-86.

Gunther McGrath, R., \& Nerkar, A. (2004). Real options reasoning and a new look at the R\&D investment strategies of pharmaceutical firms. Strategic Management Journal, 25(1), 1-21.

Hull, C. E., \& Rothenberg, S. (2008). Firm performance: The interactions of corporate social performance with innovation and industry differentiation. Strategic Management Journal, 29(7), 781-789.

Hutchison-Krupat, J., \& Kavadias, S. (2018). Organizational enablers for NPD portfolio selection. IEEE Transactions on Engineering Management, 65(1), 59-71.

Hyer, N. L., Brown, K. A., \& Zimmerman, S. (1999). A socio-technical systems approach to cell design: case study and analysis. Journal of Operations Management, 17(2), 179-203.

Jacobs, B. W. (2014). Shareholder value effects of voluntary emissions reduction. Production and Operations Management, 23(11), 1859-1874.

Jacobs, B. W., Swink, M., \& Linderman, K. (2015). Performance effects of early and late Six Sigma adoptions. Journal of Operations Management, 36, 244-257.

Jonas, D. (2010). Empowering project portfolio managers: How management involvement impacts project portfolio management performance. International Journal of Project Management, $28(8), 818-831$.

Kacperczyk, A., Beckman, C. M., \& Moliterno, T. P. (2015). Disentangling risk and change: Internal and external social comparison in the mutual fund industry. Administrative Science Quarterly, 60(2), 228-262.

Karaer, Ö., Kraft, T., \& Khawam, J. (2017). Buyer and nonprofit levers to improve supplier environmental performance. Production and Operations Management, 26(6), 1163-1190.

Kotter, J. P., \& Schlesinger, L. A. (1989). Choosing strategies for change Readings in Strategic Management (pp. 294-306): Springer.

Kuusela, P., Keil, T., \& Maula, M. (2017). Driven by aspirations, but in what direction? Performance shortfalls, slack resources, and resource-consuming vs. resource-freeing organizational change. Strategic Management Journal, 38(5), 1101-1120.

Levine, H. A. (2005). Project portfolio management. San Francisco.

Liu, G., Shah, R., \& Schroeder, R. G. (2006). Linking work design to mass customization: a sociotechnical systems perspective. Decision Sciences, 37(4), 519-545.

Lo, C. K., Tang, C. S., Zhou, Y., Yeung, A. C., \& Fan, D. (2018). Environmental Incidents and the Market Value of Firms: An Empirical Investigation in the Chinese Context. Manufacturing \& Service Operations Management. 
Malhotra, M. K., \& Mackelprang, A. W. (2012). Are internal manufacturing and external supply chain flexibilities complementary capabilities? Journal of Operations Management, 30(3), 180-200. doi: https://doi.org/10.1016/j.jom.2012.01.004

Maylor, H., Meredith, J. R., Söderlund, J., \& Browning, T. (2018). Old theories, new contexts: extending operations management theories to projects. International Journal of Operations \& Production Management, 38(6), 1274-1288.

Maylor, H., \& Turner, N. (2017). Understand, reduce, respond: project complexity management theory and practice. International Journal of Operations \& Production Management, 37(8), 10761093.

Nair, A., Nicolae, M., \& Narasimhan, R. (2013). Examining the impact of clinical quality and clinical flexibility on cardiology unit performance-Does experiential quality act as a specialized complementary asset? Journal of Operations Management, 31(7), 505-522. doi: https://doi.org/10.1016/j.jom.2013.09.001

Ocasio, W. (1997). Towards an attention-based view of the firm. Strategic management journal, 18(S1), 187-206.

Plambeck, E. L., \& Taylor, T. A. (2015). Supplier evasion of a buyer's audit: Implications for motivating supplier social and environmental responsibility. Manufacturing \& Service Operations Management, 18(2), 184-197.

Porteous, A. H., Rammohan, S. V., \& Lee, H. L. (2015). Carrots or sticks? Improving social and environmental compliance at suppliers through incentives and penalties. Production and Operations Management, 24(9), 1402-1413.

Riley, S. M., Michael, S. C., \& Mahoney, J. T. (2017). Human capital matters: Market valuation of firm investments in training and the role of complementary assets. Strategic Management Journal, 38(9), 1895-1914.

Sarkis, J. (2000). An analysis of the operational efficiency of major airports in the United States. Journal of Operations management, 18(3), 335-351.

Sarkis, J., \& Cordeiro, J. J. (2001). An empirical evaluation of environmental efficiencies and firm performance: pollution prevention versus end-of-pipe practice. European Journal of Operational Research, 135(1), 102-113.

Sarkis, J., Zhu, Q., \& Lai, K.-h. (2011). An organizational theoretic review of green supply chain management literature. International Journal of Production Economics, 130(1), 1-15.

Simar, L., \& Wilson, P. W. (2007). Estimation and inference in two-stage, semi-parametric models of production processes. Journal of econometrics, 136(1), 31-64.

Somech, A. (2006). The effects of leadership style and team process on performance and innovation in functionally heterogeneous teams. Journal of management, 32(1), 132-157.

Srivastava, M. K., \& Gnyawali, D. R. (2011). When do relational resources matter? Leveraging portfolio technological resources for breakthrough innovation. Academy of Management Journal, 54(4), 797-810.

Srivastava, S. K. (2007). Green supply-chain management: a state-of-the-art literature review. International journal of management reviews, 9(1), 53-80.

Swink, M. (2003). Completing projects on-time: how project acceleration affects new product development. Journal of Engineering and Technology Management, 20(4), 319-344.

Swink, M., \& Nair, A. (2007). Capturing the competitive advantages of AMT: Design-manufacturing integration as a complementary asset. Journal of Operations Management, 25(3), 736-754. doi: https://doi.org/10.1016/j.jom.2006.07.001

Swink, M., Talluri, S., \& Pandejpong, T. (2006). Faster, better, cheaper: A study of NPD project efficiency and performance tradeoffs. Journal of Operations Management, 24(5), 542-562.

Tang, Z., Hull, C. E., \& Rothenberg, S. (2012). How corporate social responsibility engagement strategy moderates the CSR-financial performance relationship. Journal of Management Studies, 49(7), 1274-1303.

Tong, X., Lai, K.-h., Zhu, Q., Zhao, S., Chen, J., \& Cheng, T. (2018). Multinational enterprise buyers' choices for extending corporate social responsibility practices to suppliers in emerging countries: A multi-method study. Journal of Operations Management. 
Tsai, J. Y., Raghu, T. S., \& Shao, B. B. M. (2013). Information systems and technology sourcing strategies of e-Retailers for value chain enablement. Journal of Operations Management, 31(6), 345-362. doi: https://doi.org/10.1016/j.jom.2013.07.009

Verma, D., Mishra, A., \& Sinha, K. K. (2011). The development and application of a process model for R\&D project management in a high tech firm: A field study. Journal of Operations Management, 29(5), 462-476. doi: https://doi.org/10.1016/j.jom.2010.11.010

Wiersma, E. (2007). Conditions that shape the learning curve: Factors that increase the ability and opportunity to learn. Management Science, 53(12), 1903-1915.

Winkelbach, A., \& Walter, A. (2015). Complex technological knowledge and value creation in science-to-industry technology transfer projects: The moderating effect of absorptive capacity. Industrial Marketing Management, 47, 98-108.

Yu, S., Mishra, A. N., Gopal, A., Slaughter, S., \& Mukhopadhyay, T. (2015). E-Procurement Infusion and Operational Process Impacts in MRO Procurement: Complementary or Substitutive Effects? Production and Operations Management, 24(7), 1054-1070.

Zhou, W., Huang, W., \& Zhou, S. X. (2017). Energy performance contracting in a competitive environment. Decision Sciences, 48(4), 723-765.

Forbes, April 22, 2014. https://www.forbes.com/sites/susanadams/2014/04/22/11-companiesconsidered-best-for-the-environment/\#995df7412ae9. Last accessed September 26, 2018.

Walmart 2018 Global Responsibility Report Summary.

https://www.energymanagertoday.com/walmart-releases-global-responsibility-report-inches-closer-to100-renewable-energy-goal-0177995. Last accessed on October 2, 2018. 